\title{
Revisiting chlorophyll data along the coast in north-central Chile, considering multiscale environmental variability
}

\author{
Reinterpretando datos de clorofila en la costa centro-norte de Chile, considerando \\ variabilidad ambiental de multiescala
}

VIVIAN MONTECINO ${ }^{1 *}$, M. ALEJANDRA PAREDES ${ }^{1}$, PEDRO PAOLINI $^{2} \&$ JOSÉ RUTLLANT $^{3}$

\author{
${ }^{1}$ Departamento de Ciencias Ecológicas, Facultad de Ciencias, Universidad de Chile \\ ${ }^{2}$ Centro de Estudios Espaciales \\ ${ }^{3}$ Departamento de Geofísica, Facultad de Ciencias Físicas y Matemáticas y Programa en Dinámica de la Atmósfera y el \\ Clima (PRODAC), Universidad de Chile; \\ * e-mail for correspondence: clorofil@uchile.cl
}

\begin{abstract}
Phytoplankton abundance in the surface mixed layer of the coastal ocean responds to environmental changes at various time scales. Here the "warm", "cold" and "neutral" phases of "three environmental cycles" have been jointly considered to assess chlorophyll-a (Chl- $a$ ) biomass variability for both the active and relaxed phases of the local, wind-driven coastal upwelling: (i) the interannual ENSO cycle (ii) the annual (seasonal) cycle and (iii) the intraseasonal cycle associated with equatorially-sourced, ocean trapped-waves along the coast in northern Chile. The main goal of this study is to quantitatively assess the variability of the depthintegrated Chl- $a$ biomass in the euphotic zone ( $\left.\int \mathrm{Chl}-a\right)$ in terms of an overall "environmental condition" over a $50 \mathrm{~km}$ upwelling sensitive coastal strip, revisiting published and unpublished Chl- $a$ ship $\left(\mathrm{C}_{\text {ship }}=\mathrm{Chl}-a+\right.$ Phaeopigments) data. All possible "environmental conditions" combinations were further ranked into seven "environmental indices" ranging from 0 ("absolutely cold") to 6 ("absolutely warm"). Out of 332 samples of SChl- $a, 198 / 134$ were obtained during active/relaxed upwelling conditions from which 24/38 and 30/36 samples were associated with the simultaneous occurrence of at least two "cold"/"warm" phases of the three environmental cycles ("cold"/"warm" environmental conditions), respectively. Lower SChl- $a$ values during "cold" and "warm" environmental conditions relative to the "neutral" ones reached statistical significance for both active and relaxed conditions (144/60 samples respectively). Higher turbulent mixing during "cold" environmental conditions and a deeper nutricline during "warm" ones would explain lower fChl-a-values. Satellite chlorophyll $\left(\mathrm{C}_{\mathrm{sat}}\right)$ data obtained in clear skies (active upwelling only), showed a similar distribution to those of $\int \mathrm{Chl}-a$ when classified into the corresponding "environmental indices". These results suggest that during "neutral" (transitional) "environmental conditions", nutrient supply, mean light exposure and mixing thresholds, including biological interactions, could be more effective in producing a higher phytoplankton biomass, in spite of a larger dispersion.
\end{abstract}

Key words: ENSO, Coastal trapped waves, coastal upwelling, phytoplankton biomass, AntofagastaValparaíso, Chile.

\section{RESUMEN}

La abundancia de fitoplancton en la capa de mezcla superficial del océano costero responde a cambios ambientales en diferentes escalas de tiempo. Aquí se han considerado conjuntamente las fases "cálida", "fría" y "neutra" de "tres ciclos ambientales" para estimar la variabilidad de la biomasa de la clorofila (Chl-a) para las fases activa y relajada de la surgencia costera inducida por el viento local: (i) el ciclo interanual ENOS (ii) el ciclo anual (estacional) y (iii) el ciclo intraestacional asociado con ondas oceánicas atrapadas a lo largo de la costa en el norte de Chile. El objetivo principal de este estudio es estimar cuantitativamente la variabilidad de la $\mathrm{Cl}-a$ integrada en la zona eufótica $\left(\int \mathrm{Chl}-a\right)$ en términos de una "condición ambiental" conjunta, para la banda costera de $50 \mathrm{~km}$ sensible a la surgencia, reinterpretando datos in situ de Chl- $a\left(\mathrm{C}_{\text {ship }}=\mathrm{Chl}-a+\mathrm{Feo}\right.$ pigmentos) publicados y no publicados. Todas las combinaciones posibles de las "condiciones ambientales" se ordenaron en siete "indices ambientales" que van desde 0 ("absolutamente frío") a 6 ("absolutamente cálido"). Del total de 332 muestras de $\int$ Chl- $a$, 198/134 se obtuvieron en condiciones de surgencia activa/ relajada, de las cuales 24/38 y 30/36 muestras estuvieron asociadas con al menos dos fases frías/cálidas, de los tres ciclos ambientales (condiciones ambientales "fría"/"cálida") respectivamente. Los menores valores de SChl- $a$ durante las condiciones ambientales "frías" y "cálidas" respecto de las "neutras" alcanzaron 
significancia estadística tanto en surgencia activa como relajada (144/60 muestras respectivamente). Una mayor mezcla turbulenta durante condiciones ambientales "frías" y una nutriclina más profunda durante las "cálidas" explicarían los menores valores de $\int \mathrm{Chl}-a$. Datos de clorofila satelital $\left(\mathrm{C}_{\mathrm{sat}}\right)$ obtenidos para cielos despejados (sólo surgencia activa), mostraron una distribución similar a los de la fChl- $a$ cuando se clasificaron dentro de los correspondientes "índices ambientales". Estos resultados sugieren que durante las condiciones ambientales "neutrales" (transicionales), el aporte de nutrientes, la exposición promedio a la luz y los umbrales de turbulencia, incluyendo interacciones biológicas, podrían ser más efectivos en producir una mayor biomasa fitoplanctónica, a pesar de una mayor dispersión.

Palabras clave: ENOS, ondas atrapadas a la costa, surgencia costera, biomasa fitoplanctónica, AntofagastaValparaíso, Chile.

\section{INTRODUCTION}

Phytoplankton distribution in the central part (16-26을 $\mathrm{S}$ ) of the Humboldt Current System (HCS), has been characterised by low spatial/ high temporal variability, as shown through satellite chlorophyll $\left(\mathrm{C}_{\mathrm{sat}}\right)$ data averaged in space over $100 \mathrm{~km}$ next to the coast (Thomas et al. 2001, Montecino et al. 2006). These large temporal changes are due to the phytoplankton response to quasi-weekly upwelling favourable wind events, which depends primarily on the mean depth of the nutricline. Here we hypothesise that these nutricline mean depth is the fundamental parameter explaining phytoplankton abundance associated to any particular upwelling wind event, as it changes according to the phase of intraseasonal Coastal Trapped Waves (CTW's); the annual cycle and the interannual El Niño/Southern Oscillation (ENSO) cycle (Rutllant \& Montecino 2002).

The local atmospheric forcing seems to be always active along north-central Chile, largely independent of the phase of lower-frequency environmental cycles (e.g., Rutllant et al. 2004). Although environmental variability on interannual (ENSO) scales has been noticed as important, particularly during strong El Niño/ La Niña events, weak seasonal variability patterns in the phytoplankton concentration have been reported between $18-30^{\circ} \mathrm{S}$ through remote sensing of ocean colour, with $\mathrm{C}_{\text {sat }}$ maxima centred on austral summer coinciding with the season of maximum strength of the upwelling- favourable winds along the coast (Thomas et al. 2001). However seasonal changes seem to be moderate in strength off Perú and stronger at mid- and high latitudes off Chile (Montecino et al. 2006). Intraseasonal variability in the depth of the nutricline is dominated by equatorially-sourced CTWs, as reflected in coherent changes in coastal sea level (e.g., Shaffer et al. 1997) and sea surface temperature along the west coast of South America, the latter showing a $90^{\circ}$ phase lag relative to the sea level (Hormazábal et al. 2001, Rutllant et al. 2004).

Global ocean primary production has been positively linked to cold SSTs as a proxy of nutrient availability (Behrenfeldt \& Falkowski. 1997). Temperature, nutrients, light-shade adaptation (Falkowski 1981) and species growth rates (Cloern et al. 1995), change the abundance of phytoplankton Chl- $a$ biomass and the chlorophyll:carbon ratio. This variability is not absent in the Chilean coastal region where higher phytoplankton biomass (estimated as Chlorophyll-a like pigments from ship measurements, $\mathrm{C}_{\text {ship }}$ ) is mostly restricted to a coastal strip of $50 \mathrm{~km}$ (Montecino et al. 1998, Stuart et al. 2004), although high pigment concentrations associated with filaments extending several hundred kilometres from coastal upwelling centres in the HCS have been detected in satellite pigment and SST imagery (Yáñez et al. 1995, Carr 2002, Marín \& Delgado 2003).

Revisiting published and unpublished data of $\mathrm{C}_{\text {ship }}$ (Chl- $a+$ Phaeopigments) along the northcentral Chilean coast, the present study aims at a quantitative assessment of the column-integrated Chl- $a$ biomass variability over a $50 \mathrm{~km}$ "upwelling sensitive" coastal strip (Fig. 1). Since concurrent cycles at various time scales are modulating the nutricline depth, the specific phases of intraseasonal, anual and interannual environmental cycles were established for each datum. The effect of multiscale environmental cycles over the Chl-a biomass variability (Rutllant \& Montecino 2002), leads to the hypothesis that differences should arise when at least two cold, warm or neutral phases of the three environmental cycles are simultaneously considered. 


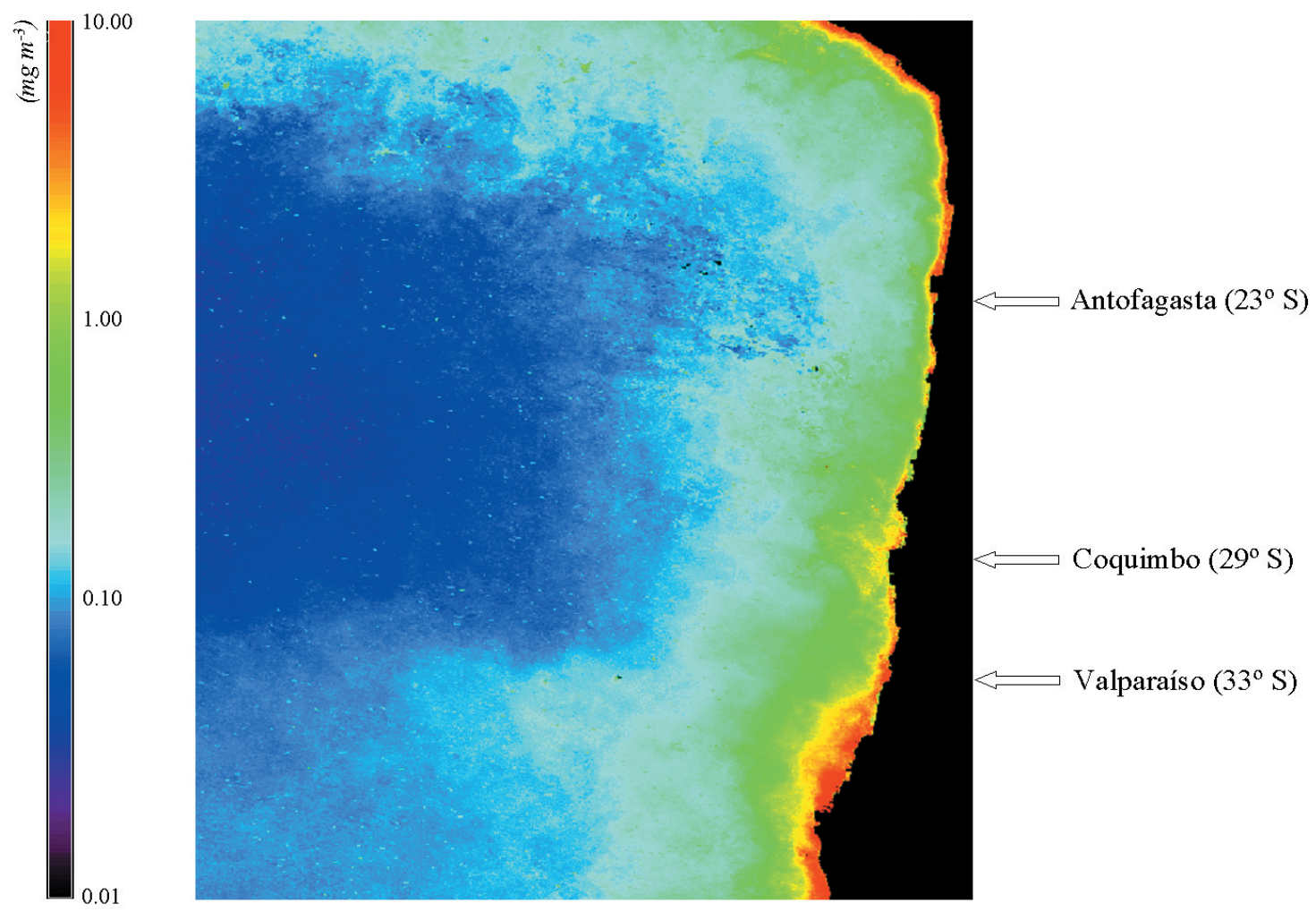

Fig. 1: The location of three coastal upwelling sites in north-central Chile $\left(23^{\circ}-46^{\circ} \mathrm{S}\right)$ where $\mathrm{C}_{\text {ship }}$ samples were collected. These are indicated over a map of surface chlorophyll concentrations, estimated from the first six years of SeaWiFS ocean colour measurements for the Humboldt Current system off western South America (means for austral summer- from hierarchical data files; courtesy of Andrew Thomas).

Ubicación de los tres lugares de surgencia costera en el centro-norte de Chile (23ํ-46 $\left.{ }^{\circ} \mathrm{S}\right)$ donde se recolectaron las muestras para $\mathrm{C}_{\text {ship. }}$. Estos aparecen indicados sobre un mapa de concentraciones superficiales de clorofila, estimados para los primeros seis años de mediciones SeaWiFs del color del mar para el sistema de corrientes de Humboldt frente a Sudamérica occidental (promedios para el verano austral a partir de archivos de datos jerárquicos, cortesía de Andrew Thomas).

\section{MATERIAL AND METHODS}

To examine the phytoplankton Chl- $a$ biomass distribution during different phases of interanual, seasonal and intraseasonal environmental cycles, that have been labelled as "warm", "cold" and "neutral" (transitional) phases, the euphotic zone depth-integrated Chl$a$ biomass ( $\int \mathrm{Chl}-a$ ) values were calculated within the upwelling-sensitive coastal strip off north-central Chile. The $\mathrm{C}_{\text {ship }}$ (Chl- $a+$ Phaeopigments) data were selected from coastal stations $(<50 \mathrm{~km})$ of different cruises (Table 1) including spring values off Valparaíso. In order to compare the $\mathrm{C}_{\text {ship }}$ with the $\mathrm{C}_{\text {sat }}$ data, the values during the active phase of the upwelling cycle (clear sky conditions), have been considered separately from those corresponding to the relaxed phase of the upwelling, when overcast skies prevail (e.g., Rutllant et al. 1998, Garreaud et al. 2002).

The phase separation of the intraseasonal and interannual cycles was made following previous work (Rutllant \& Montecino 2002), in which "cold"/"warm" phases were considered as proxies for "shallower"/ "deeper" nutriclines, without any association with the potential temperature effect on phytoplankton growth. Other biological effects as grazing during warm conditions (Pizarro et al. 2002) and changes in sedimentation processes (González et al. 1998) or increased primary production during cold conditions (Rutllant \& Montecino 2002) were also not considered here. Each $\int \mathrm{Chl}-a$ value was 
labelled according to the phase (cold- neutralwarm) of: (a) the ENSO (interannual) cycle using the Multivariate ENSO Index (www.cdc.noaa.gov/ kew/MEI/); (b) the annual cycle, as defined by sea surface temperature (SST) monthly means (SHOA- Chile, 1996) (Table 2), and (c) the intraseasonal cycles associated with coastal trapped waves (CTWs), obtained from daily sea level data for Caldera (27ํ S), supplied by the Sea Level Centre,
University of Hawaii and band-passed (28-70 days) with a Butterworth filter. Consistent with the reported phase lag between SST and sealevel in those CTWs (Hormazábal et al. 2001), "cold"/"warm" intraseasonal phases were assigned when the sea-level was rising/falling, with transition conditions in between (Rutllant \& Montecino 2002, Rutllant et al. 2004). The same protocol was used for the available oceancolour data $\left(\mathrm{C}_{\mathrm{sat}}\right)$.

TABLE 1

List of nominal sites from north to south $\left(26-33^{\circ} \mathrm{S}\right)$ of available $\mathrm{C}_{\text {ship }}$ data at different periods, locations or cruise name and maximum depth $(\mathrm{m})$ of integration of $\mathrm{C}_{\text {ship }}$ (Max $\int$ depth). To assign $\mathrm{C}_{\text {ship }}$ values, years and month of sampling were used for ENOS cycles. For the seasonal cycle see Table 2 (authors of the related publications can be found in the references)

Nómina de sitios de norte a sur (26-33을 $\mathrm{S}$ ) con disponibilidad de datos de $\mathrm{C}_{\text {ship }}$ para diferentes períodos, lugares o nombre de crucero y profundidad máxima (m) de integración de $\mathrm{C}_{\text {ship }}$ (Max $\int$ depth). Para adscribir los valores de $\mathrm{C}_{\text {ship }}$ a los ciclos ENOS se utilizaron los meses y años de muestreo. Para el ciclo estacional ver Tabla 2 (los autores de las publicaciones correspondientes se encuentran en la bibliografía)

\begin{tabular}{|c|c|c|c|c|c|}
\hline Site & Year & Month & Location or cruise* & $\operatorname{Max} \int \mathrm{depht}$ & Author \\
\hline Antofagasta & 1989 & Nov-Dec & Mejillones & 11 & Marín et al. (1993) \\
\hline Antofagasta & 1990 & Jan-Dec & Mejillones & 48 & Marín et al. (1993) \\
\hline Antofagasta & 1991 & Jan-Dec & Mejillones & 59 & Marín et al (1993) \\
\hline Antofagasta & 1993 & Apr-Dec & Antofagasta bay & 45 & Rodríguez et al. (1996) \\
\hline Antofagasta & 1993 & Nov-Dec & IFOP* & 25 & Morales et al. (1996) \\
\hline Antofagasta & 1994 & Jan-Dec & Antofagasta bay & 40 & Rodríguez et al. (1996) \\
\hline Antofagasta & 1994 & Feb & IFOP* & 100 & Morales et al. (2001) \\
\hline Antofagasta & 1994 & May & IFOP* & 100 & Morales et al. (2001) \\
\hline Antofagasta & 1995 & Jan-May & Antofagasta bay & 30 & Rodríguez et al. (1996) \\
\hline Antofagasta & 1996 & July-Dec & Mejillones & 60 & Ulloa et al. (2001) \\
\hline Antofagasta & 1997 & Jan & Sectorial* & 74 & Rutllant \& Montecino (2002) \\
\hline Antofagasta & 1997 & July & Sectorial* & 66 & Rutllant \& Montecino (2002) \\
\hline Antofagasta & 1997 & Jan-Dec & Mejillones & 60 & Ulloa et al. (2001) \\
\hline Antofagasta & 1998 & Jan & Mejillones & 60 & Ulloa et al. (2001) \\
\hline Coquimbo & 1987 & Nov & Cruz Grande & 47 & Rutllant \& Montecino (2002) \\
\hline Coquimbo & 1988 & Nov & Cruz Grande & 47 & Rutllant \& Montecino (2002) \\
\hline Coquimbo & 1992 & Apr & JGOFS* & 47 & Rutllant \& Montecino (2002) \\
\hline Coquimbo & 1992 & Jun & JGOFS* & 66 & Rutllant \& Montecino (2002) \\
\hline Coquimbo & 1992 & Oct & JGOFS* & 60 & Rutllant \& Montecino (2002) \\
\hline Coquimbo & 1993 & Sep & JGOFS* & 74 & Rutllant \& Montecino (2002) \\
\hline Coquimbo & 1994 & Jan-Feb & JGOFS* & 48 & Rutllant \& Montecino (2002) \\
\hline Coquimbo & 1995 & Jan & JGOFS* & 59 & Rutllant \& Montecino (2002) \\
\hline Coquimbo & 1995 & July & JGOFS* & 84 & Rutllant \& Montecino (2002) \\
\hline Coquimbo & 1996 & July & JGOFS* & 73 & Rutllant \& Montecino (2002) \\
\hline Coquimbo & 1997 & Feb & JGOFS* & 70 & Rutllant \& Montecino (2002) \\
\hline Coquimbo & 1997 & Nov & JGOFS* & 82 & Rutllant \& Montecino (2002) \\
\hline Valparaíso & 1996 & Nov & Valparaíso bay & 19 & Sievers \& Vega (2000) \\
\hline Valparaíso & 1997 & Nov & Valparaíso bay & 27 & Sievers \& Vega (2000) \\
\hline Valparaíso & 2000 & Sep-Dec & Valparaíso bay & 45 & Pablo Muñoz (personal communication) \\
\hline Valparaíso & 2001 & Sep-Dec & Valparaíso bay & 48 & Pablo Muñoz (personal communication) \\
\hline
\end{tabular}

*IFOP:Instituto de Fomento Pesquero.

*JGOFS:Joint Global Ocean Flux Studies. 
As suggested previously (Rutllant \& Montecino 2002) the simultaneous occurrence of at least two cold/warm conditions $(\mathrm{ww}=\mathrm{w} ; \mathrm{cc}=\mathrm{c})$ in the concurrent three scales of variability defines a resulting "cold"/"warm" Environmental Condition (EC) for the Chl-a biomass abundance; otherwise the EC is labelled as "neutral" (Table 3). For all possible EC realisations $\left(3^{3}\right.$ =27) an arbitrary discrete numerical value from zero to six $(\mathrm{EI}=$ Environmental Index $)$ ranks them from "absolutely cold" $(0=\mathrm{ccc})$ to "absolutely warm" (6 = www), passing through "mostly cold", "weakly cold", "neutral", "weakly warm" and "mostly warm" (Table 3). Increasing EIs discrete values (0 to 6) also represent increasing water column stability and decreasing nutrient availability, both affecting phytoplankton biomass abundance.

The significance of the differences between the integrated $\mathrm{C}_{\text {ship }}$ values for the warm, cold and transition ECs was assessed separately for the upwelling active and upwelling relaxed data by nonparametric Kruskal-Wallis test by ranks (Sokal \& Rohlf 1981). The same procedure was applied to the $\mathrm{C}_{\mathrm{sat}}$ data, which only correspond to the upwelling active (clear skies) cycle. These comparisons were conducted using standart statistical procedures. The shape of the distribution of $\int \mathrm{Chl}-a$ and $\mathrm{C}_{\mathrm{sat}}$ data into the EI values was tested for significance through quantile regression analysis with a quadratic fit for the 10-95 percentils using the "quantreg" $\mathrm{R}$ library software (http://www.R-project.org/) (Cade et al. 1999, Knight \& Ackerly 2002)

TABLE 2

Monthly mean sea-surface temperatures $\left({ }^{\circ} \mathrm{C}\right)$ at three different upwelling centers obtained from the first coastal isotherm (Chilean Oceanographic Atlas 1996). Warm (grey and bold), transition (white and italics) and cold (grey and normal) seasonal conditions define the annual thermal cycle

Promedio mensual de temperaturas superficiales $\left({ }^{\circ} \mathrm{C}\right)$ en tres diferentes centros de surgencia obtenido desde la primera isoterma costera (Atlas Oceanográfico de Chile 1996). Las condiciones estacionales cálida (gris y negritas), transición (blanco y cursivas) y fría (gris y normal) definen el ciclo anual termal

\begin{tabular}{lcccccccccccc}
\hline Zone & Jan & Feb & Mar & Apr & May & Jun & Jul & Aug & Sep & Oct & Nov & Dec \\
\hline Antofagasta & $\mathbf{2 0}$ & $\mathbf{2 1}$ & $\mathbf{2 0}$ & 19 & 18 & 16 & 16 & 16 & 15 & 17 & 18 & 18 \\
Coquimbo & $\mathbf{1 8}$ & $\mathbf{1 6}$ & $\mathbf{1 7}$ & 15 & 15 & 14 & 13 & 13 & 13 & 14 & 15 & $\mathbf{1 6}$ \\
Valparaíso & $\mathbf{1 7}$ & $\mathbf{1 5}$ & $\mathbf{1 5}$ & 14 & 14 & 14 & 13 & 13 & 13 & 13 & 14 & $\mathbf{1 5}$ \\
\hline
\end{tabular}

TABLE 3

Environmental Conditions (EC), and the Environmental Index (EI). Conditions with at least two "cold/warm" components are shaded. The EI values (0-6) result from the sum of cold (0), transition (1) and warm (2) conditions from the three environmental cycles considered here

Condiciones ambientales (EC) e índice ambiental (EI). Condiciones con al menos dos componentes "fría/cálida" están sombreadas. Los valores EI (0-6) resultan de la suma de las condiciones fría (0), transición (1) y cálida (2) a partir de los tres ciclos ambientales aquí considerados

\begin{tabular}{|c|c|c|c|c|c|c|c|}
\hline $\begin{array}{l}\text { EC } \\
\text { EI }\end{array}$ & $\begin{array}{c}\text { Absolutely cold } \\
0\end{array}$ & $\begin{array}{c}\text { Mostly cold } \\
1\end{array}$ & $\begin{array}{c}\text { Weakly cold } \\
2\end{array}$ & $\begin{array}{l}\text { Neutral } \\
3\end{array}$ & $\begin{array}{c}\text { Weakly warm } \\
4\end{array}$ & $\begin{array}{c}\text { Mostly warm } \\
5\end{array}$ & $\begin{array}{c}\text { Absolutely warm } \\
6\end{array}$ \\
\hline & $\operatorname{ccc}$ & $\mathrm{ccn}$ & $\mathrm{ccw}$ & wnc & wwe & wwn & www \\
\hline & & cnc & cwc & wen & wcw & wnw & \\
\hline & & $\mathrm{ncc}$ & wcc & nwc & $\mathrm{cwW}$ & nww & \\
\hline & & & cnn & $\mathrm{nnn}$ & wnn & & \\
\hline & & & $\mathrm{ncn}$ & ncw & nwn & & \\
\hline & & & nnc & cwn & nnw & & \\
\hline & & & & cnw & & & \\
\hline
\end{tabular}


$\mathrm{C}_{\mathrm{sat}}$ data were extracted from SeaWiFs images obtained from the Distribution Active Archive Center (DAAC), Goddard Space Flight Center (GSFC), NASA, and selected according to cloud coverage criteria. For image processing SeaDAS V4.3 software for Linux and OC4 algorithm were used. In northern Chile, $\mathrm{C}_{\mathrm{sat}}$ data were obtained from seven sampling points slightly south of Mejillones peninsula, (station 15 in Pizarro et al. 2002) within the $70.67-70.79^{\circ} \mathrm{W}$ and $23.31-23.36^{\circ} \mathrm{S}$ rectangle, and seven sampling points from Punta Coloso (Station 25, in Pizarro et al. 2002) within $70.60-70.68^{\circ} \mathrm{W}$ and $23.75-23.83^{\circ}$ $\mathrm{S}$ rectangle for 1997, 1998, 1999 and $2000(\mathrm{n}=$ $27,15,33,85$ images respectively). $\mathrm{C}_{\mathrm{sat}}$ values for each EI were plotted in the same way as it was done with $\int \mathrm{Chl}-a$. From a total of $242 \mathrm{C}_{\text {sat }}$, 120/34 samples were associated with "cold"/ "warm" environmental conditions.

\section{RESULTS}

$\mathrm{C}_{\text {ship }}$ data concentrated off Antofagasta $\left(23^{\circ} \mathrm{S}\right)$ and Coquimbo $\left(30^{\circ} \mathrm{S}\right)$ with some sparse information off Caldera $\left(27^{\circ} \mathrm{S}\right)$ and Valparaíso $\left(33^{\circ} \mathrm{S}\right)$. Altogether, about $72 \%$ of the samples correspond to distances within $10 \mathrm{~km}$ from the coast and $20 \%$ of the samples were either between $10-20$ or $40-50 \mathrm{~km}$.

Warm, cold and neutral seasons along the coast of north-central Chile, based on the SST monthly means (Table 2), indicate that the annual amplitude of SST changes from $6{ }^{\circ} \mathrm{C}$ (northern Chile) to $4{ }^{\circ} \mathrm{C}$ (central Chile). The cold season (July to October) in central Chile (Valparaíso) lags by about one month the northern one (Antofagasta to Coquimbo).

From a total of 332 SChl- $a$ samples, 198/134 were obtained during active/relaxed upwelling conditions. For the active/relaxed upwelling subsets, $24 / 38$ and 30/36 samples were associated with cold/warm ECs, respectively, in contrast with 144/60 samples taken during neutral ECs, in which the largest variability was found (Fig. 2).

The highest $\int \mathrm{Chl}-a$ biomass was found during "neutral" ECs, representing transitions from "cold" to "warm" or "warm" to "cold". In fact, a unimodal distribution with lower maximum values during "absolutely cold" (EI $=0)$, "mostly cold" (EI = 1), "mostly warm"
$(\mathrm{EI}=5)$ and "absolutely warm" $(\mathrm{EI}=6) \mathrm{EC}$ conditions was found (Fig. 3A). Mean values of SChl- $a$ ranged from 29.55 to $47.52 \mathrm{mg}$ Chl- $a+$ $\mathrm{Php} \mathrm{m}^{-2}$. The corresponding average figures for the transition groups ranged from 31.32 to 102.76 mg Chl- $a+$ Php m ${ }^{-2}$.

$\int$ Chl- $a$ differences between three categories of EI's ("absolutely", "mostly" and "weaklycold", "neutral" and the "absolutely", "mostly" and "weakly-warm") were significant (KruskalWallis test, $\mathrm{H}_{2,198}=8.13, \mathrm{P}=0.0172$ ) for the active upwelling samples (Fig. 2A) as they were for the relaxed upwelling ones (Fig. 2B) (Kruskal-Wallis test, $\mathrm{H}_{2,134}=10.02, \mathrm{P}=$ 0.0067).

To overcome deficiencies in the spatial and temporal coverage, SChl- $a$ data were complemented with ocean colour satellite $\left(\mathrm{C}_{\mathrm{sat}}\right)$ data obtained in clear skies, conditions that prevail during active upwelling only. Since most of the satellite data were obtained for year 2000, they were biased towards cold interannual conditions (La Niña). Although $\mathrm{C}_{\text {sat }}$ data arranged into EI bins indicate a similar pattern as with $\int \mathrm{Chl}-a$ (Fig. 3B), significance in the differences between cold, warm and neutral $\mathrm{C}_{\mathrm{sat}}$ values was not attained (Kruskal-Wallis test, $\mathrm{H}_{2,122}=1.63, \mathrm{P}=0.4422$ ).

\section{DISCUSSION}

The period of re-examination of $\mathrm{C}_{\text {ship }}$ data (Table 1) started with a warm phase (El Niño) of the ENSO cycle in 1987, followed by a cold one (La Niña) in 1988. A long and moderate warm event occurred between 1991 and 1995. During this 12-13 year period, measurements off the Mejillones peninsula area and at the outer section of the Valparaíso bay, allowed SChl- $a$ comparisons in different phases of intraseasonal, annual and ENSO cycles. Since available data for northern Chile were scarce, Valparaíso data had to be included although Valparaíso lies at the poleward edge of the seasonally-persistent strong upwelling zone (Mackas et al. 2006).

Based on Moraga et al. (1994) and Escribano et al. (2004), seasonal-intraseasonal and interannual variability in the mean depth of the thermocline base for Coquimbo $\left(30^{\circ} \mathrm{S}\right)$ and Antofagasta $\left(23^{\circ} \mathrm{S}\right)$ can be described to oscillate between $85 \pm 35 \mathrm{~m}$ and $42 \pm 32.5$ (El 

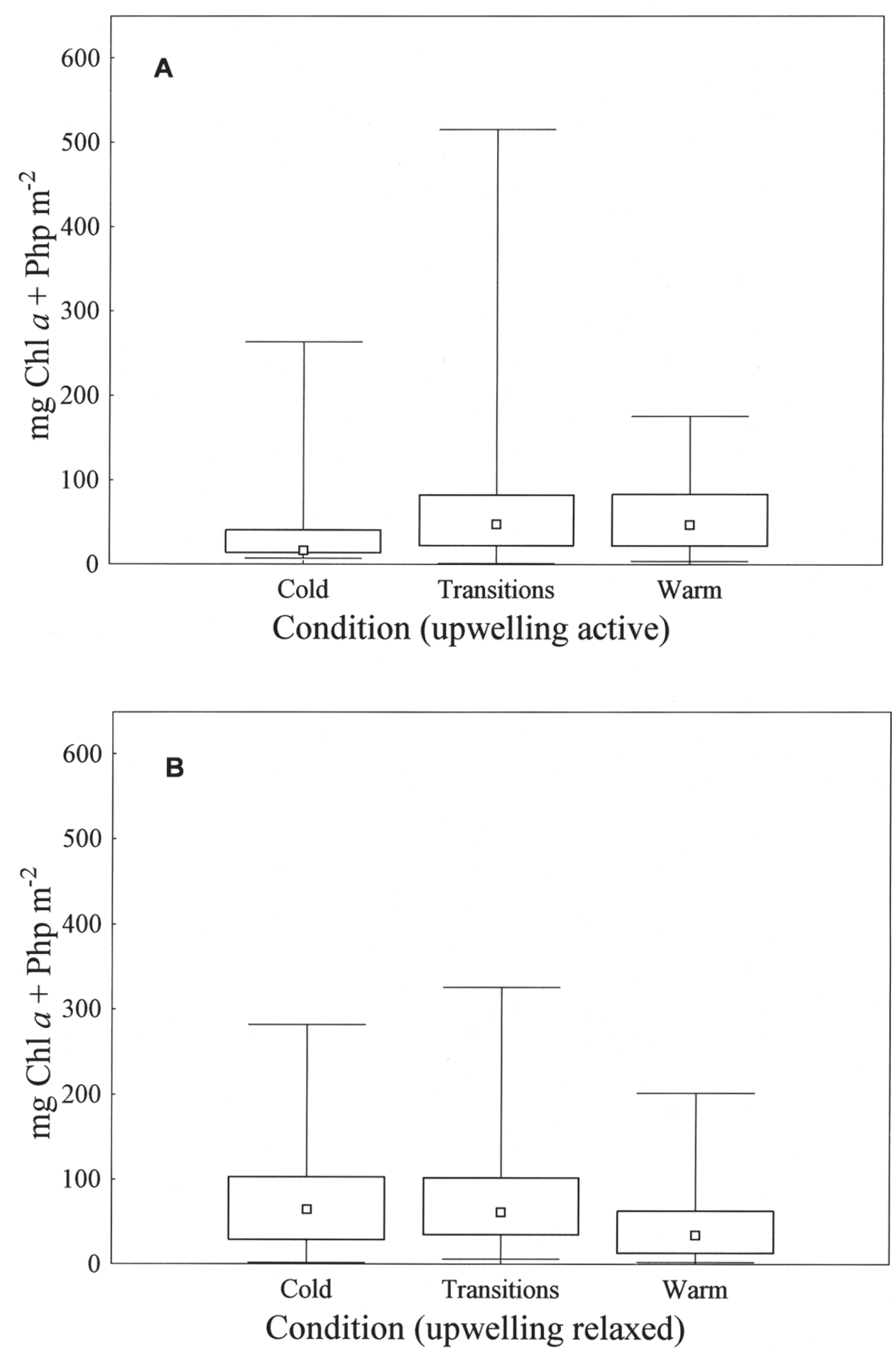

Fig. 2: Minima, maxima and medians of integrated chlorophyll-a + Phaeopigments (Chl- $a+$ Php) for "cold", "neutral" (transition) and "warm" environmental conditions (ECs), for active (A) and relaxed upwelling conditions (B). The results of the statistical analysis are indicated in the text.

Mínimos, máximos y medianas de los valores integrados de clorofila-a + Feopigmentos (Chl- $a+$ Php) para condiciones ambientales (ECs) "fría", "neutra" (transición) y "cálida", para condiciones de surgencia activa (A) y relajada (B). Los resultados del análisis estadístico se indican en el texto. 
(A)

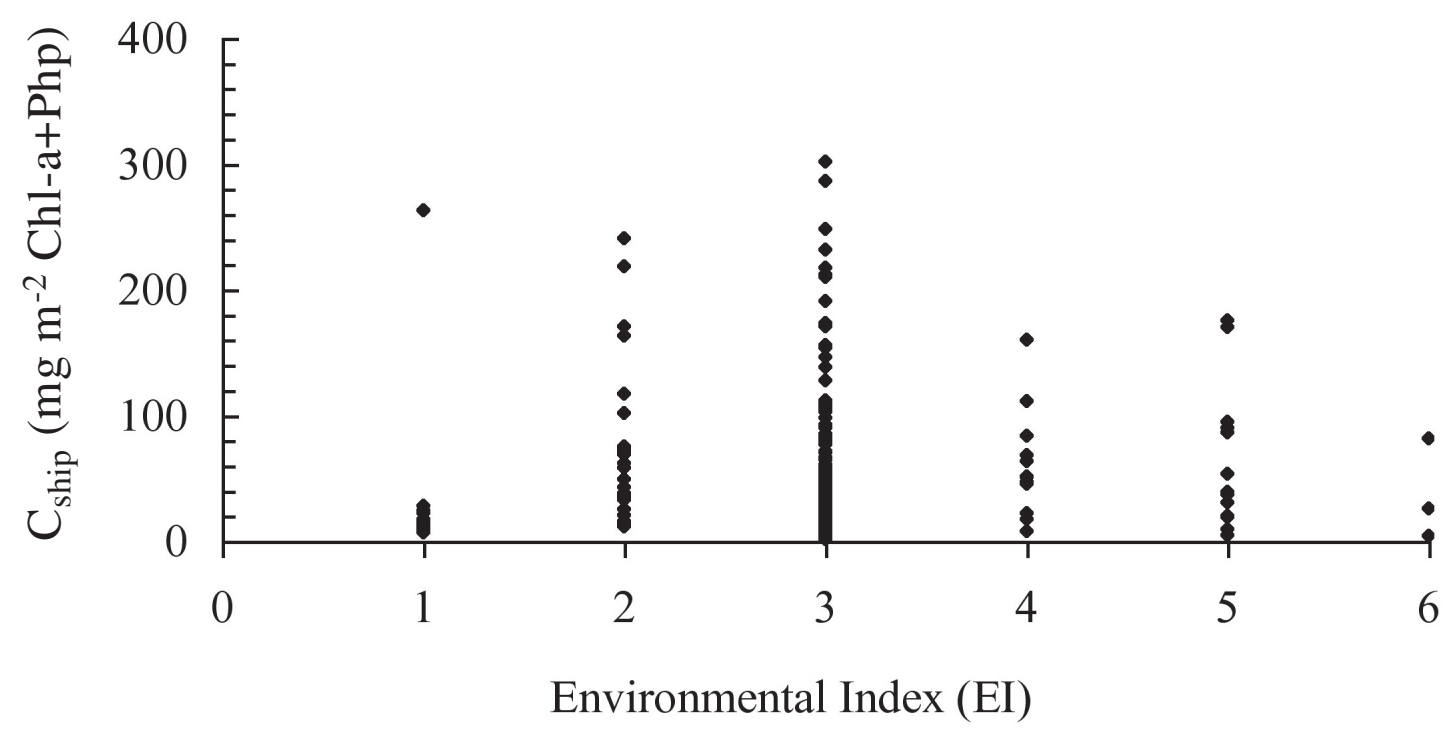

(B)

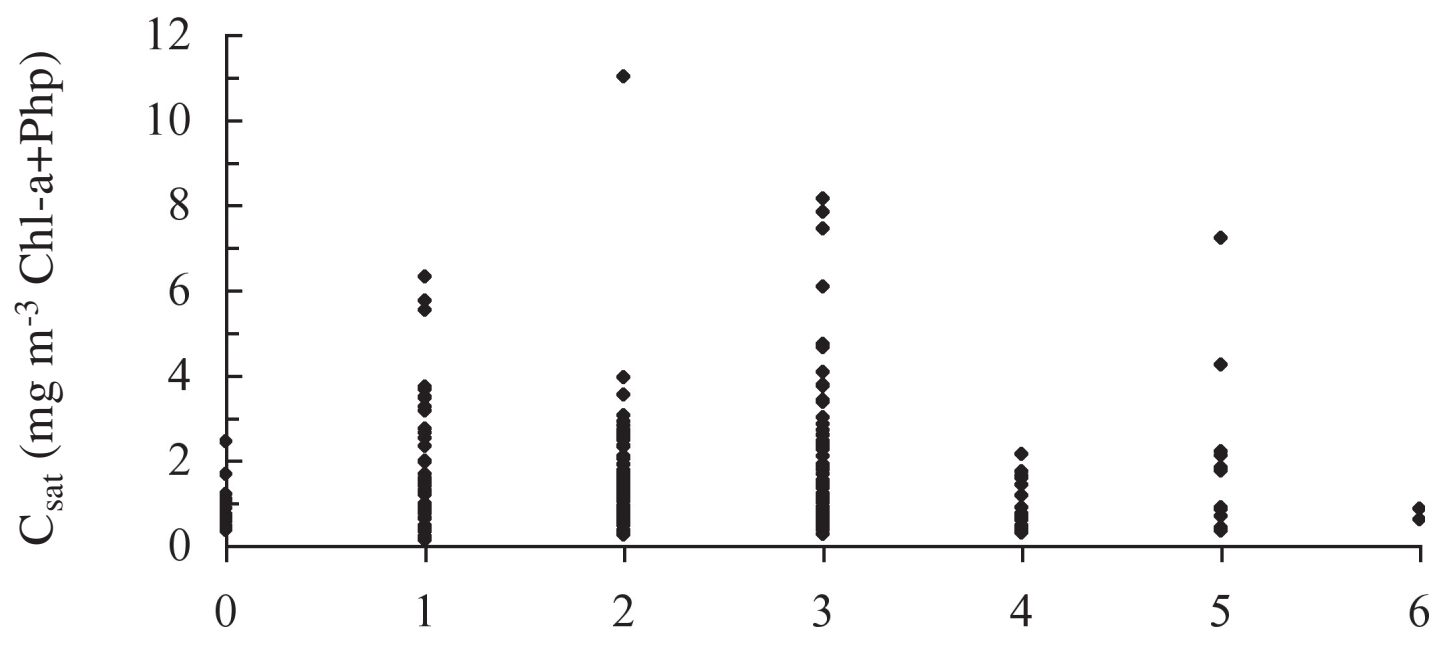

Environmental Index (EI)

Fig. 3: (A) Distribution of integrated chlorophyll-a + Phaeopigments (Chl- $a+\mathrm{Php})$ values, as a function of the Environmental Index (EI), from in situ measurements during upwelling active conditions in Antofagasta, Coquimbo and Valparaíso. The analysis of the resulting unimodal relationship, showed significant quadratic regression $(P=0.04)$ throughout percentils 10 to 85. (B) Distribution of $\mathrm{C}_{\mathrm{sat}}$ values as a function of the Environmental Index (EI) at two sites off the Mejillones Peninsula during upwelling active conditions. The analysis of the resulting unimodal relationship showed significant quadratic regression $(\mathrm{P}<0.001)$ throughout percentils 10 to 75.

(A) Distribución de los valores integrados de clorofila-a + Feopigmentos (Chl- $a+\mathrm{Php})$ en función del Indice Ambiental (EI), de mediciones in situ en Antofagasta, Coquimbo y Valparaíso durante condiciones de surgencia activa. El análisis de la relación unimodal resultante, mostró regresiones cuadráticas significativas $(\mathrm{P}<0,05)$ en los percentiles 10 al 85 . (B)Distribución de valores de $\mathrm{C}_{\mathrm{sat}}$ en función del Indice Ambiental (EI) en dos sitios frente a Península Mejillones durante condiciones de surgencia activa. El análisis de la relación unimodal resultante, mostró regresiones cuadráticas significativas $(\mathrm{P}<0,0001)$ en los percentiles 10 al 75 . 
Niño) and between $35 \pm 15 \mathrm{~m}$ and $20 \pm 10 \mathrm{~m}$ (La Niña), respectively. Since geographic differences appear smaller than seasonal or interannual variability, the results reported here should be valid for the merged data from northern and central Chile. Moreover, the lower mean depth of the thermocline base at Coquimbo is compensated by stronger mean southerly winds there (e.g., Hormazábal et al. 2001). Also during El Niño years, the combined seasonal- intraseasonal variability represented by the departures from the mean depth is largest due to stronger intraseasonal oscillations during austral summer just before the onset of El Niño (e.g., Shaffer et al. 1997).

Above the thermocline base low salinity and oxygen- rich subantarctic waters prevail, except during El Niño's when they might become mixed with higher salinity and temperature subtropical waters. Below the thermocline high salinity, nutrient and dissolved carbon dioxide (equatorial subsurface waters) prevail, with very low oxygen content (Blanco et al. 2002, Montecino et al. 2006).

Besides the multiscale environmental cycles influencing the nutrient availability through oscillations in the mean thermo-nutricline depth, the significant differences in JChl- $a$ median values found between cold, warm and neutral ECs can be also attributed to biological changes as increase/decrease of new/ regenerated production, size structure of phytoplankton assemblages and low Chl- $a$ abundance during cold conditions along the Chilean northern coast (Montecino \& Quiroz 2000, Pizarro et al. 2002, Iriarte \& González 2004). The dominance of microphytoplankton cells and biological shifts in size composition of phytoplankton assemblages when $\int \mathrm{Chl}-a$ increases (Iriarte \& González 2004), explain both the presence of outlayers and the large variability in the observed values during neutral (transition) ECs (Fig. 3). Therefore, higher $\int$ Chl- $a$ stocks found during neutral ECs can be understood as coupling of the classic template of nutrient supply and mean light exposure of Margalef's diagram, for both small and large phytoplankton fractions (Cullen et al. 2002).

Here we have expanded on the results found by Rutllant \& Montecino (2002) while interpreting changes in Chl- $a$ biomass and primary production between the active and relaxed phases of the local wind-driven upwelling. In fact the expected high turbulent mixing/low stability in the upper water column during active upwelling in "cold" conditions, results in lower Chl- $a$ abundance in spite of the shallower nutricline (larger nutrient supply). With maximum stratification of the upper water column during "warm" conditions and relaxed upwelling, light availability is larger (except for self-shading) but the nutrient supply in the euphotic zone is less. Therefore increasing EIs also represent decreasing mean nutrient availability (deeper nutricline). These results are consistent with the effects of the upper ocean physical processes on pelagic communities and the biological system, specifically the competing influences of water column stability on the light and nutrient requirements for phytoplankton production, suggested to be maximized when both substrates are adequate (Gargett \& Marra 2002).

Mackas et al. (2006) comparing different upwelling areas report temporal and spatial variability of the forcing and response, including seasonal and interannual variability. In this overview, the typical phytoplankton abundances are referred to the differences in the extension of the high pigment region between winter and summer with a temporal mismatch between wind-forcing and phytoplankton response on annual scales off Perú. At a larger scale, $\mathrm{C}_{\mathrm{sat}}$ in Pacific and Atlantic mid latitude eastern boundary currents share common seasonal patterns in the extensions of the upwelling sensitive strip.

The altered hydrographical conditions during the 1997-1998 El Niño (Blanco et al. 2002) were not reflected in phytoplankton biomass abundance in northern Chile, although temperature and oxygen increased (Ulloa et al. 2001). This was probably due to the narrowing of the region with colder upwelled water off northern Chile (Blanco et al. 2002, Torres et al. 2002), in which the majority of the samples were obtained $(10 \mathrm{~km}$ from the coast). Biological consequences of interannual variability in non-coastal upwelling areas (Chávez 2006), relate to different phenomena than those reported here.

Contrasting with the results for the $\int \mathrm{Chl}-a$ values, the lack of significance in the differences between $\mathrm{C}_{\mathrm{sat}}$ values from cold to neutral ECs can be in the first place attributed 
to the generally cold interannual conditions during the period in which data were available. Since only near-surface Chl- $a$ can be estimated with ocean-colour data, the coexistence within the euphotic zone of more species that thrive at intermediate levels of turbulent mixing and light availability with a characteristic larger dispersion could influence this result. In summary, these results would indicate that it is the whole water column that is more sensitive to the multiscale ECs in stimulating higher $\int C h l-a$ stocks during transitional stages.

Finally, since neutral conditions are much more frequent than the absolutely cold/warm ones, as they include transitions for each one of the three environmental cycles considered here, care should be taken when comparing in-situ and time- averaged satellite-derived data off north-central Chile.

\section{ACKNOWLEDGEMENTS}

Several researchers are acknowledged for kindly making published and unpublished data available to us: J. L. Blanco, M. Castillo, R. Escribano, S. Hormazábal, V. Marín, C. Morales, P. Muñoz, G. Pizarro \& H. Sievers. Rosa Astoreca helped in building the data base and doing preliminary analysis. Zaida Salinas and Benjamín Rosenbluth contributed with the analysis of windstress data and the filtering of sea level data. Andrew Thomas at University of Maine is acknowledged for Figure 2. Specific projects supported data gathering of $\mathrm{V}$. Montecino and J. Rutllant: JGOFS-Chile, FONDECYT 1960875; 1040891, FONDAPHumboldt, CIMAR-CONA. The 2002 Project in Marine Sciences and Program in Dynamics of the Atmosphere and Climate (PRODAC), both from the Department of Research (DI), Universidad de Chile, supported this research work. The assistance of Rodolfo Godoy and Karla Leal from the Centre for Space Studies, Universidad de Chile, in processing satellite imagery is also acknowledged.

\section{LITERATURE CITED}

BEHRENFELD M \& P FALKOWSKI (1997) Photosynthetic rates derived from satellite based chlorophyll concentration. Limnology and Oceanography 42: 1-20.
BLANCO J, M CARR, A THOMAS \& P STRUB (2002) Hydrographic conditions off northern Chile during the 1996-1998 La Niña and El Niño events. Journal of Geophysical Research 107:1-19.

CADE BS, JW TERREL \& RL SHROEDER (1999) Estimating effects of limiting factors with regression quantiles. Ecology 80: 311-323.

CARR ME (2002) Estimation of potential productivity in eastern boundary currents using remote sensing. Deep-Sea Research II 49: 59-80.

CHÁVEZ FP (2006) Biological consequences of interannual to multidecadal variability. In: Robinson AR \& K Brink (eds) The sea, Vol. 14A: 21-59. Harvard University Press, Cambridge, Massachusetts, USA.

CLOERN JE, C GRENZ \& L VIDERGAR-LUCAS (1995) An empirical model of the phytoplankton chlorophyll: carbon ratio-the conversion factor between productivity and growth rate. Limnology and Oceanography 40: 1313-1321.

CULLEN JJ, PJS FRANKS, DK KARL \& A LONGHURST 2002 Physical Influences on marine ocosystem dynamics. In: Robinson AR, J McCarthy \& B Rotshield (eds) The sea: 297-336. Harvard University Press, Cambridge, Massachusetts, USA.

ESCRIBANO R, G DANERI, L FARÍAS, VA GALLARDO, HE GONZÁLEZ, D GUTIÉRREZ, CB LANGE, CE MORALES, O PIZARRO, O ULLOA \& M BRAUN (2004) Biological and chemical consequences of the 1997-1998 El Niño in the Chilean coastal upwelling system: a synthesis. Deep Sea Research II 51: 2389-2411.

FALKOWSKY PG (1981) Light-shade adaptation and assimilation numbers. Journal of Plankton Research 3: 203-216.

GARREAUD R, J RUTLLANT \& H FUENZALIDA (2002) Coastal lows along the subtropical west coast of South America: mean structure and evolution. Monthly Weather Review 130: 75-88.

GONZÁlEZ HE, G DANERI, D FIGUEROA, JL IRIARTE, $\mathrm{N}$ LEFEVRE, $\mathrm{G}$ PIZARRO, $\mathrm{R}$ QUINONES, M SOBARZO \& A TRONCOSO (1998) Flujo de carbono en la zona norte de la corriente de Humboldt durante El Niño. Revista Chilena de Historia Natural 71: 429-458.

GARGETT A \& J MARRA (2002) Effects of upper ocean physical processes (turbulence, advection and airSea interaction) on oceanic primary production. In: Robinson A, J McCarthy \& B Rotschild (eds) The sea: 19-49. Harvard University Press, Cambridge, Massachusetts, USA.

HORMAZÁBAL S, G SHAFFER, J LETELIER \& O ULLOA (2001) Local and remote forcing of sea surface temperature in the coastal upwelling system off Chile. Journal of Geophysical Research 106: 16657-16671.

IRIARTE JL \& H GONZÁLEZ (2004) Phytoplankton size structure during and after the El Niño of 1997-1998 in a coastal upwelling area of the northern Humboldt Current system. Marine Ecology Progress Series 269: 83-90.

KNIGHT C \& D ACKERLY (2002) Variation in nuclear DNA content across environmental gradients: a quantile regression analysis. Ecology Letters 5: 6676.

MACKAS DL, PT STRUB, A THOMAS \& V MONTECINO (2006) Eastern ocean boundaries. Pan-regional overview. In: Robinson AR \& $\mathrm{KH}$ Brink (eds) The sea, Vol. 14A: 21-59. Harvard University Press, Cambridge, Massachusetts, USA. 
MARÍN V, L RODRÍGUEZ, L VALLEJO, J FUENTESECA \& E OYARCE (1993) Efectos de la surgencia costera sobre la productividad primaria primaveral de bahía Mejillones del sur (Antofagasta, Chile). Revista Chilena de Historia Natural 66: 479-491.

MARÍN V \& L DELGADO (2003) S-chlorophyll squirts at $30^{\circ} \mathrm{S}$ off the Chilean coast (eastern South Pacific): feature-tracking analysis. Journal of Geophysical Research 108: 3378.

MONTECINO V, G PIZARRO \& D QUIROZ (1998) Primary production off the Chilean coast. In: Hollowary G, P Muller \& D Henderson (eds) Proceedings of the Aha Huliko'a Hawaiian Winter Workshop: 69-76. Biotic impact of extratropical climate variability in the Pacific. School of Ocean and Earth Science and Technology (SOEST) Special Publication. University of Hawaii at Manoa, Honolulu, USA.

MONTECINO V \& D QUIROZ (2000) Specific primary production and phyoplankton cell size structure in an upwelling area off the coast of Chile $\left(30^{\circ} \mathrm{S}\right)$. Aquatic Science 62: 1-17.

MONTECINO V, T STRUB, F CHÁVEZ, A THOMAS, J TARAZONA \& T BAUMGARTNER (2006) Biophysical interactions off western South America. In: Robinson AR \& KH Brink (eds) The sea: 329-390. Harvard University Press, Cambridge, Massachusetts, USA.

MORAGA J, A VALLE-LEVINSON \& JL BLANCO (1994) Hidrografía y dinámica de la capa superior del océano en la zona costera del Pacífico suroriental $\left(30^{\circ} \mathrm{S}\right)$. Investigación Pesquera (Chile) 38: 55-73.

MORALES C, J BLANCO, M BRAUN, H REYES \& N SILVA (1996) Chlorophyll-a distribution and associated oceanographic conditions in the upwelling region off northern Chile during the winter and spring 1993. Deep-Sea Research 43: 267-289.

MORALES C, J BLANCO, M BRAUN \& N SILVA (2001) Chlorophyll-a distribution and mesoscale physical processes in upwelling and adjacent oceanic zones off northern Chile (summer-autumn 1994). Journal Marine Biological Association (United Kingdom) 81: 193-206.

PIZARRO G, J IRIARTE \& V MONTECINO (2002) Variabilidad de la producción primaria y bio-óptica a mesoescala frente a las costas de Antofagasta (23$24^{\circ}$ S) durante la transición a El Niño 1997-1998. Revista Chilena de Historia Natural 75: 201-215.

RODRÍGUEZ L, R ESCRIBANO, G GRONE, C IRRIBARREN \& H CASTRO (1996) Ecología del fitoplancton en la Bahía de Antofagasta $\left(23^{\circ} \mathrm{S}\right)$, Chile. Revista de Biología Marina de Valparaíso (Chile) 31: 65-80

RUTLLANT J, H FUENZALIDA, R TORRES \& D FIGUEROA (1998) Interacción océano-atmósfera-

Associate Editor: Iván Gómez

Received August 5, 2004; accepted November 8, 2005 tierra en la Región de Antofagasta (Chile, 23ํㅗ S): experimento DICLIMA. Revista Chilena de Historia Natural 71: 405-427.

RUTLLANT J \& V MONTECINO (2002) Multiscale upwelling forcing cycles and biological response off north-central Chile. Revista Chilena de Historia Natural 75: 217-231.

RUTLLANT J, I MASOTTI, J CALDERÓN \& S VEGA (2004) A comparison of spring coastal upwelling off central Chile at the extremes of the 1996-1997 ENSO cycle. Continental Shelf Research 24: 773 787.

SHOA-Chile (1996) Atlas oceanográfico de Chile. Servicio Hidrográfico y Oceanográfico de la Armada de Chile. Inscripción $\mathrm{N}^{\circ} 97.527$ del 29 de agosto de 1996. Volumen 1, $234 \mathrm{pp}$.

SHAFFER G, O PIZARRO, L DJURFELDT, S SALINAS \& J RUTLLANT (1997) Circulation and lowfrequency variability near the Chilean coast: Remotely forced fluctuations during the 1991-92 El Niño. Journal Physical Oceanography 27: 217-230.

SIEVERS H \& S VEGA (2000) Respuesta físico-química de la bahía de Valparaíso a la surgencia generada en Punta Curaumilla y al fenómeno El Niño. Revista de Biología Marina y Oceanografía (Chile) 35: 153168.

SOKAL RR \& FJ ROHLF (1981) Biometry: the principles and practice of statistics in biological research. W.H. Freeman \& Company, San Francisco, California, USA. 859 pp.

STUART $\mathrm{V}, \mathrm{O}$ ULLOA, $\mathrm{G}$ ALARCÓN, S SATHYENDRANATH, H MAJOR, E HEAD \& T PLATT (2004) Bio-optical characteristics of phytoplankton populations in the upwelling system off the coast of Chile. Revista Chilena de Historia Natural 77: 87-105.

THOMAS AC, JL BLANCO, ME CARR, PT STRUB \& J OSSES (2001) Satellite-measured chlorophyll and temperature variability off northern Chile during the 1996-1998 La Niña and El Niño. Journal of Geophysical Research 106: 899-915.

TORRES R, D TURNER, J RUTLLANT, M SOBARZO, T ANTEZANA \& H GONZÁLEZ (2002) $\mathrm{CO}_{2}$ outgassing off central Chile (31-30 $\mathrm{S})$ and northern Chile (24-23은 $\mathrm{S}$ ) during austral summer 1997: the effect of wind intensity on the upwelling ventilation of $\mathrm{CO}_{2}$-rich waters. Deep-Sea Research I 49: 14131429.

ULLOA O, R ESCRIBANO, S HORMAZÁBAL, R QUIÑONES, R GONZÁLEZ \& M RAMOS (2001) Evolution and biological effects of the 1997-98 El Niño in the upwelling ecosystem off northern Chile. Geophysical Research Letters 28: 1591-1594.

YÁÑEZ E，A GONZÁLEZ \& MA BARBIERI (1995) Estructura térmica superficial del mar asociada a la distribución espacio-temporal de sardina y anchoveta en la zona norte de Chile entre 1987 y 1992. Investigaciones Marinas (Chile) 23: 123-147. 